\title{
Microbiological changes and quality characteristics of dried persimmon by chlorine dioxide gas fumigation treatment
}

\author{
Hey-Kyung Moon ${ }^{2}$, Su-Won Lee ${ }^{1}$, Wha Jin Lee ${ }^{1}$, Abul Hossein ${ }^{1}$, Seul Lee ${ }^{3}$, \\ Jong-Kuk Kim ${ }^{1,4 *}$ \\ ${ }^{1}$ Department of Food and Food-Service Industry, Kyungpook National University, Sangju 37224, Korea \\ ${ }^{2}$ Center for Scientific Instruments, Kyungpook National University, Daegu 41566, Koreaa \\ ${ }^{3}$ Department of Food Science and Biotechnology, Kyungpook National University, Daegu 41566, Korea \\ ${ }^{4}$ Food and Bio-industry Research Institute, Kyungpook National University, Daegu 41566, Korea
}

\section{이산화염소 가스 훈증 처리에 따른 곶감의 미생물학적 변화 및 품질특성}

\author{
문혜경 ${ }^{2} \cdot$ 이수원 ${ }^{1} \cdot$ 이화진 ${ }^{1} \cdot \mathrm{Abul} \mathrm{Hossein}^{1} \cdot$ 이슬 $^{3} \cdot$ 김종국 ${ }^{1,4 *}$ \\ 경북대학교 식품외식산업학과, ${ }^{2}$ 경북대학교 공동실험실습관, ${ }^{3}$ 경북대학교 식품공학부, ${ }^{4}$ 식품생물산업연구소
}

\begin{abstract}
This study was conducted to investigate the effect of chlorine dioxide fumigation as a substitute for sulfur fumigation which has been used as a method to prevent the quality change of persimmon during storage and distribution process. Dried persimmons were treated with chlorine dioxide gas concentration $(0,1530$, and $45 \mathrm{ppm})$ and time $(0,15,30$, and $45 \mathrm{~min})$ and microbiological changes, texture properties and color of the treated samples were investigated during storage at room temperature. Total aerobic bacteria, yeast and mold numbers after chlorine dioxide gas fumigation were decreased when compared with the control group. The inhibitory effects of total aerobic bacteria, yeast, and mold were observed during storage. The texture properties and color value of dried persimmons were not affected by chlorine dioxide gas fumigation concentration and time. There was no difference in quality between chlorine dioxide gas fumigation treatment group and control group. These results suggested that chlorine dioxide gas fumigation treatment can be utilized as a processing technique to secure microbiological storage stability of dried persimmons.
\end{abstract}

Key words : chlorine dioxide gas, microbiological changes, texture, color value

\section{서 론}

곶감은 떫은 감을 박피한 후 건조한 것으로 고려시대부 터 이용되고 있는 대표적인 과실 건조가공품이다(1). 곶감 은 감 수확 시기에 다량 생산되는 감의 이용성을 증대시키 기 위한 중요한 수단으로 건조 시 단맛이 생감에 비해 약 4 배 증가하는데 주요 생산지는 경북 상주, 충북 영동, 경남

*Corresponding author. E-mail : kjk@knu.ac.kr

Phone : 82-54-530-1305, Fax : 82-54-530-1309

Received 14 June 2017; Revised 3 August 2017; Accepted 25 August 2017.

Copyright (c) The Korean Society of Food Preservation. All rights reserved.
함안 및 전북 완주 등이 있으며, 그 중 상주 지역이 전국 생산량의 $60 \%$ 를 차지한다 $(2,3)$.

곶감은 대부분 천일건조를 이용하여 제조되어 건조하는 동안 이물질의 혼입, 감에 존재하는 폴리페놀성 물질의 산 화에 의한 흑변의 문제가 발생한다. 건조 시 습한 날씨가 지속될 경우에는 곰팡이 증식 등에 의한 품질저하가 우려된 다. 이러한 곶감의 품질 저하를 방지하고 저장성을 향상시 키기 위해 농가에서는 유황훈증 처리를 사용하여 왔다(4). 아황산가스는 미생물의 세포막 기능을 저해시키고 단백질 과 $\mathrm{mRNA}$ 를 불활성화하여 미생물에 직접적인 위해 작용을 한다(5). 그러나 아황산가스는 미생물뿐만 아니라 인체에 도 유해한 작용을 하기 때문에 적절한 사용량이 요구되며, 잔류 문제가 없다 하더라도 소비자의 기피 현상이 일어날 
수 있으므로 이를 대체할 수 있는 위생적인 처리 방법이 필요한 실정이다 $(6,7)$.

이산화염소는 농산물의 미생물 제어를 위해 이용되는 소독제 중 하나로, 공기 중에서 쉽게 분해되어 소독제 처리 후 식품에 소독성분이 잔류하지 않고, $\mathrm{pH}$ 변화와 관계없이 살균력이 유지되는 것으로 알려져 있다(8-10). 이산화염소 는 액체 상태보다 기체형태로 이용될 경우 투과성이 높아 액체보다 살균력이 우수하여 농산물 저장 및 유통 시 보다 효과적으로 미생물을 제어할 수 있는 것으로 알려져 있다 (11).

이산화염소의 살균효과를 검증하기 위해 농산물에 적용 시킨 다양한 연구들이 이루어져 왔는데, Youm 등(12)은 salad에 이산화염소를 처리하여 저장성을 향상시킬 수 있음 을 보여주었으며, Lee 등(13)은 수출 딸기에 이산화염소 가스 처리를 통해 병원성 Escherichia coli와 Salmonella spp. 저감화 효과를 입증하였다. 최근에는 서방형 이산화염소 가스를 이용한 이슬송이버섯의 저장 중 품질 변화를 확인한 연구가 진행되었다(14)

본 연구에서는 저장 및 유통과정 중 곶감의 품질 변화를 저해하기 위한 방법으로 기존에 사용되어 왔던 유황 훈증 대체 물질로 이산화염소의 훈증 처리 효과를 확인하고자 하였다.

\section{재료 및 방법}

\section{실험재료}

본 실험에서 사용한 시료는 경북 상주지역에서 2015년 생산된 상주 둥시 곶감을 상주시농협공판장에서 구입하여 사용하였다.

\section{이산화염소 가스 훈증 및 저장 조건}

본 연구에서 사용한 이산화염소 가스 훈증 장치는 Fig. 1 과 같다. 이산화염소 가스 훈증 장치는 이산화염소 $\left(\mathrm{ClO}_{2}\right)$ 가스를 생성하는 가스발생기(CA-300series, Purgofarm, Hwaseong, Korea), 생성된 이산화염소가스를 모아둔 챔버 에서 일정한 농도로 가스를 투입하고 측정하는 가스투입 기, 시료를 훈증처리할 수 있는 훈증 챔버로 구성되어 있다. 이때 이산화염소 가스의 농도를 조절하는 센서(ATi Series F12 Gas Transmitter, Delph, UK)를 사용하였고, 상대습도는 가습기에 습도조절센서(DH-2341A, Ko Lobster, Busan Korea)를 연결하여 조절하였다. 이산화염소 가스 훈증처리 는 $20^{\circ} \mathrm{C}$, 상대습도 $60 \%$ 조건에서 $15,30,45 \mathrm{ppm}$ 농도로 각각 $15,30,45$ 분간 처리하였다. 곶감은 $\mathrm{PP}$ 재질의 포장지에 각각 3 개씩 포장하여 입구를 개봉한 후 이산화염소 훈증 처리된 시료들을 $25 \pm 3^{\circ} \mathrm{C}$ 에서 3 일 동안 저장하면서 미생물 수 및 품질 변화를 측정하였다(13).

\section{미생물 수 측정}

시료 $50 \mathrm{~g}$ 과 $0.1 \%$ 멸균 펩톤 수 $50 \mathrm{~mL}$ 를 멸균 bag에 넣고 10 분 동안 균질화한 후, 추출액을 Whatman No. 2 여과 지를 이용하여 여과한 액을 $0.1 \%$ 멸균 펩톤 수로 희석한 후 각각의 배지에 분주하여 실험하였다. 총 호기성 세균은 plate count agar(PCA)를 사용하여 $37^{\circ} \mathrm{C}$ 에서 2 일간 배양하 였고, 효모 및 곰팡이는 potato dextrose agar(PDA)를 사용하 여 $25^{\circ} \mathrm{C}$ 에서 3 일간 배양한 후 형성된 colony를 계수하였다. 검출된 미생물 수는 시료 $\mathrm{g}$ 당 colony forming unit(CFU)으 로 나타내었다.

\section{물성 측정}

물성 측정은 곶감을 직경 $5.0 \mathrm{~mm}$ probe가 장착된 texture analyser(CT3 4500, Brookfield Engineering Laboratories, Inc., Middleboro, USA)를 사용하여 실온에서 측정하였다. Texture profile analysis(TPA) test는 pre test speed $5.0 \mathrm{~mm} / \mathrm{s}$, test speed $5.0 \mathrm{~mm} / \mathrm{s}$ 의 속도로 두께의 $50 \%$ 까지 도달했을 때의 hardness(g), adhesiveness(mJ), resilience, cohesiveness, springiness $(\mathrm{mm})$, gumminess $(\mathrm{g})$, chewiness $(\mathrm{mJ})$ 값을 측정하 여 평균값을 나타내었다.

\section{색도 측정}

곶감의 색도는 색차계(UltraScan Pro Spectrophotometer, HunterLab Inc., Reston, Virginia, USA)를 사용하여 각 시료 표면의 Hunter $\mathrm{L}, \mathrm{a}, \mathrm{b}$ 값을 측정하여 평균 \pm 표준편차로 나타 내었으며, 이 때 사용된 표준 백판의 $\mathrm{L}, \mathrm{a}, \mathrm{b}$ 값은 각각 $\mathrm{L}=99.26, \mathrm{a}=-0.14, \mathrm{~b}=-0.16$ 이었다. 색차(total color difference) 값은 Hunter L, a, b 값을 사용하여 다음 식에 의하여 계산하 였다.

$$
\Delta \mathrm{E}=\left[\left(\mathrm{L}_{\text {sample }}-\mathrm{L}_{\text {control }}\right)^{2}+\left(\mathrm{a}_{\text {sample }}-\mathrm{a}_{\text {control }}\right)^{2}+\left(\mathrm{b}_{\text {sample }}-\mathrm{b}_{\text {control }}\right)^{2}\right]^{1 / 2}
$$

\section{통계처리}

본 실험결과의 유의성 검증은 Statistical Analysis System(SAS, Version 9.2, Cary, NC, USA)을 이용하여 ANOVA 분석을 실시한 후, Duncan's multiple range test로 $\mathrm{p}<0.05$ 수준에서 유의차 검정을 실시하였다.

\section{결과 및 고찰}

\section{미생물 수 변화}

이산화염소 가스 훈증 처리에 따른 곶감의 미생물 수 변화를 알아보기 위해 이산화염소 가스 농도 및 처리 시간 을 다르게 하여 3 일 동안 총 세균 수, 효모 수 및 곰팡이 수를 측정하였다.

이산화염소 가스 훈증 처리에 따른 곶감의 총 세균 수 
A

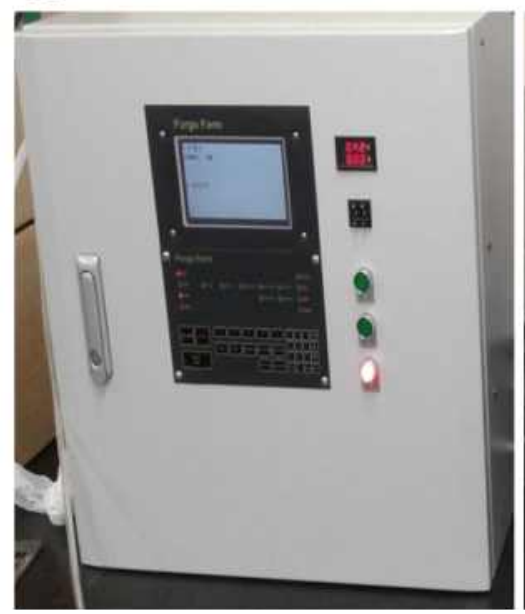

B

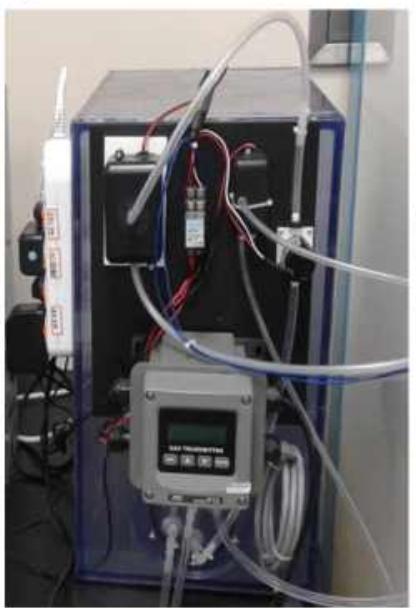

C

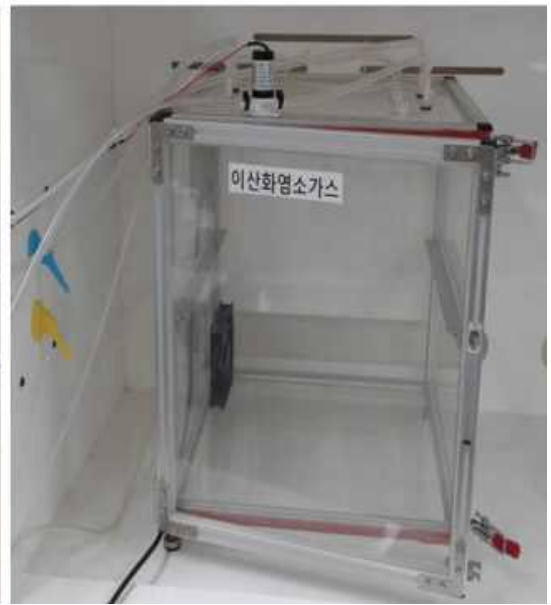

D

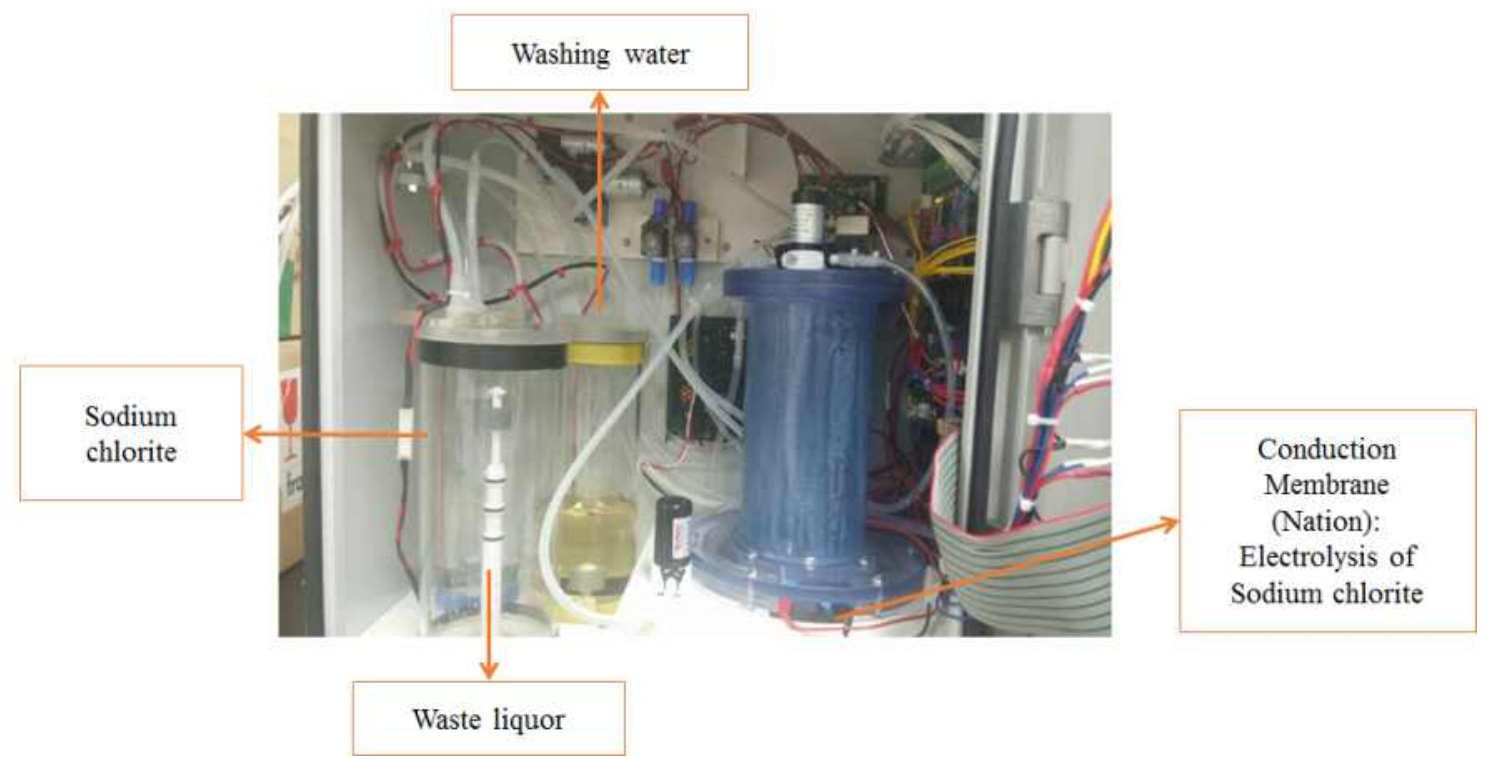

Fig. 1. The photo of chlorine dioxide gas $\left(\mathrm{ClO}_{2}\right)$ machine.

$\mathrm{A}, \mathrm{ClO}_{2}$ generation; $\mathrm{B}, \mathrm{ClO}_{2}$ gas feeder; C, Fumigation chamber; $\mathrm{D}, \mathrm{ClO}_{2}$ gas generating system.

변화는 Table 1 에 나타내었다. 대조구는 저장 기간 3 일 동안 총 세균 수가 급격하게 증가하여 초기 균수 $22.67 \mathrm{CFU} / \mathrm{g}$ 과 비교하여 약 30 배 높은 수치를 나타내었다. 반면 이산화염 소 가스 훈증 처리 시에는 저장 기간 동안 총 세균 수의 증가폭이 감소하였다. $15 \mathrm{ppm}$ 처리 구간에서는 훈증 시간 이 증가함에 따라 총 세균 수 증가폭이 감소하였으며, 30 $\mathrm{ppm}$ 처리 구간에서는 훈증 시간이 30 분, 45 분인 구간에서 는 저장 1 일 째 세균이 검출되지 않았으며, 저장 3 일째에는 대조구와 비교하여 총 세균 수가 약 $92 \%$ 감소하였다. 45 $\mathrm{ppm}$ 처리 구간에서는 훈증 시간과 관계없이 모든 구간에서 세균이 검출되지 않았으며, 훈증 시간을 30 분, 45 분 처리하 였을 때는 저장 3 일 동안 세균이 검출되지 않았습니다. 이산화염소 가스 훈증 처리에 따른 곶감의 효모 수 변화
는 Table 2에 나타내었다. 대조구의 효모 수는 저장 1 일 째와 비교하여 3 일 째에는 $41.67 \mathrm{CFU} / \mathrm{g}$ 으로 약 4 배 증가하 였다. $15 \mathrm{ppm}$ 처리 시에는 훈증 시간 증가 시 대조구와 비교하여 효모 수 증가폭은 감소하였으며, 45 분 동안 훈증 시 저장 1 일째에는 효모가 검출되지 않은 것으로 나타났다. $30 \mathrm{ppm}$ 처리 시에는 훈증 시간과 관계없이 저장 1 일째 모든 구간에서 효모가 검출되지 않았으며, 45 분 처리 시에 는 저장 기간 동안 효모가 검출되지 않았다. $45 \mathrm{ppm}$ 처리 구간에서는 훈증 시간과 관계없이 모든 구간에서 효모가 검출되지 않았다.

이산화염소 가스 훈증 처리에 따른 곶감의 곰팡이 수 변화는 Table 3에 나타내었다. 대조구의 곰팡이 수는 저장 
Table 1. Changes of total bacterial number in dried persimmon treated with different concentration of chlorine dioxide gas and time during storage

(unit: $\mathrm{CFU} / \mathrm{g}$ )

\begin{tabular}{|c|c|c|c|c|}
\hline \multirow{2}{*}{$\begin{array}{c}\mathrm{ClO}_{2} \text { gas } \\
\text { concentration (ppm) }\end{array}$} & \multirow{2}{*}{$\begin{array}{l}\text { Time } \\
(\mathrm{min})\end{array}$} & \multicolumn{3}{|c|}{ Drying period (day) } \\
\hline & & 1 & 2 & 3 \\
\hline \multirow[t]{2}{*}{0} & 0 & $22.67 \pm 1.32^{1 / 22)(z 3)}$ & $400.00 \pm 25.64^{\text {ay }}$ & $698.67 \pm 45.12^{\mathrm{ax}}$ \\
\hline & 15 & $7.33 \pm 0.52^{\mathrm{bz}}$ & $64.33 \pm 3.87^{\text {by }}$ & $377.33 \pm 14.32^{b x}$ \\
\hline \multirow[t]{3}{*}{15} & 30 & $5.00 \pm 0.26^{\mathrm{cz}}$ & $33.33 \pm 3.48^{\text {cy }}$ & $210.00 \pm 18.46^{c x}$ \\
\hline & 45 & $4.33 \pm 0.18^{\mathrm{cz}}$ & $33.33 \pm 2.54^{\text {cy }}$ & $128.33 \pm 10.67^{\mathrm{dx}}$ \\
\hline & 15 & $3.33 \pm 0.15^{\text {dy }}$ & $3.33 \pm 0.96^{\mathrm{dy}}$ & $73.33 \pm 4.35^{\mathrm{ex}}$ \\
\hline \multirow[t]{3}{*}{30} & 30 & - & $2.67 \pm 0.18^{\mathrm{dy}}$ & $63.67 \pm 3.74^{e x}$ \\
\hline & 45 & - & $1.33 \pm 0.21^{\mathrm{dy}}$ & $55.33 \pm 4.21^{\mathrm{ex}}$ \\
\hline & 15 & - & $1.03 \pm 0.09^{\mathrm{dx}}$ & $1.00 \pm 0.0 \mathrm{I}^{\mathrm{fx}}$ \\
\hline \multirow[t]{2}{*}{45} & 30 & - & - & - \\
\hline & 45 & - & - & - \\
\hline
\end{tabular}

${ }^{1)}$ Values are means \pm SD $(n=3)$.

2)a-t The values with different letters in the same column are significantly different $(\mathrm{p}<0.05)$.

3) $x-2$ The values with different letters in the same low are significantly different $(\mathrm{p}<0.05)$.

Table 2. Changes of yeast population in dried persimmon treated with different concentration of chlorine dioxide gas and time during storage

\begin{tabular}{|c|c|c|c|c|}
\hline \multirow{2}{*}{$\begin{array}{c}\mathrm{ClO}_{2} \text { gas } \\
\text { concentration (ppm) }\end{array}$} & \multirow{2}{*}{$\begin{array}{l}\text { Time } \\
\text { (min) }\end{array}$} & \multicolumn{3}{|c|}{ Drying period (day) } \\
\hline & & 1 & 2 & 3 \\
\hline \multirow[t]{2}{*}{0} & 0 & $10.67 \pm 1.21^{1 / 22) \times 3)}$ & $15.00 \pm 1.84^{\text {ay }}$ & $41.67 \pm 3.56^{\text {ay }}$ \\
\hline & 15 & $9.67 \pm 0.85^{\text {by }}$ & $10.67 \pm 0.98^{\text {by }}$ & $16.00 \pm 1.27^{b x}$ \\
\hline \multirow[t]{3}{*}{15} & 30 & $3.33 \pm 0.27^{\mathrm{cy}}$ & $9.00 \pm 0.72^{\mathrm{cx}}$ & $10.00 \pm 0.98^{\mathrm{cx}}$ \\
\hline & 45 & - & $3.00 \pm 0.12^{\mathrm{dy}}$ & $4.67 \pm 0.37^{\mathrm{dx}}$ \\
\hline & 15 & - & $1.67 \pm 0.05^{\mathrm{ey}}$ & $3.00 \pm 0.24^{\mathrm{dx}}$ \\
\hline \multirow[t]{3}{*}{30} & 30 & - & $1.33 \pm 0.01^{\mathrm{ey}}$ & $1.83 \pm 0.07^{\mathrm{dx}}$ \\
\hline & 45 & - & - & - \\
\hline & 15 & - & - & - \\
\hline \multirow[t]{2}{*}{45} & 30 & - & - & - \\
\hline & 45 & - & - & - \\
\hline
\end{tabular}

\footnotetext{
${ }^{1)}$ Values are means $\pm \mathrm{SD}(\mathrm{n}=3)$.

2)a-c The values with different letters in the same column are significantly different $(\mathrm{p}<0.05)$.

${ }^{3 \times x-2}$ The values with different letters in the same low are significantly different $(p<0.05)$.
}

기간 동안 약 8배 증가하였으며, 이산화염소 가스 훈증 처리 시에는 농도 및 시간과 관계없이 저장 1 일째에는 모든 구간 에서 곰팡이가 검출되지 않았다. $15 \mathrm{ppm}, 30 \mathrm{ppm}$ 를 각각 15 분, 30 분, 45 분 처리할 경우 훈증 농도 및 시간이 증가할수 록 검출되는 곰팡이 수는 감소하였다. $45 \mathrm{ppm}$ 을 15 분, 30 분, 45 분 처리 시 저장 2 일째까지 곰팡이는 검출되지 않았으며,
저장 3 일째에는 농도에 관계없이 동일한 수의 곰팡이가 검출되었다.

$\mathrm{Ku}$ 등(15)은 양송이버섯에 이산화염소를 처리한 후 저장 기간 동안 미생물 수를 측정한 결과, 저장기간이 경과함에 따라 이산화염소를 처리한 경우 대조구와 비교하여 호기성 균, 효모 및 곰팡이수가 모두 감소하였다고 보고하여 본 실험과 일치하는 결과를 보였다. 농산물의 종류, 농도 습도, 시간 등은 이산화염소의 살균효과에 영향을 주는 것으로 알려져 있으며(16-19), Mahmound 등(17)과 Bhaget 등(18) 은 딸기와 토마토의 미생물 저감효과는 이산화염소 가스의 농도와 시간을 증가시켰을 때 높아진다고 보고하여 본 실험 과 같은 경향을 나타내었다. 위의 결과로 미루어 볼 때 이산 화염소 훈증 처리는 곶감의 미생물 증식 억제에 효과를 가지며, 저장 및 유통 시 곶감의 품질 유지에 기여할 수 있을 것으로 생각된다.

Table 3. Changes of mold number in dried persimmon treated with different concentration of chlorine dioxide gas and time during storage

(unit: $\mathrm{CFU} / \mathrm{g}$ )

\begin{tabular}{|c|c|c|c|c|}
\hline \multirow{2}{*}{$\begin{array}{c}\mathrm{ClO}_{2} \text { gas } \\
\text { concentration (ppm) }\end{array}$} & \multirow{2}{*}{$\begin{array}{l}\text { Time } \\
(\mathrm{min})\end{array}$} & \multicolumn{3}{|c|}{ Drying period (day) } \\
\hline & & 1 & 2 & 3 \\
\hline \multirow[t]{2}{*}{0} & 0 & $102.05 \pm 8.74^{1 / 22) z 33}$ & $548.26 \pm 35.27^{\text {ay }}$ & $800.85 \pm 68.54^{2 x}$ \\
\hline & 15 & - & $80.33 \pm 8.51^{\text {by }}$ & $400.33 \pm 26.74^{b x}$ \\
\hline \multirow[t]{3}{*}{15} & 30 & - & $12.33 \pm 1.04^{\mathrm{cy}}$ & $230.67 \pm 15.68^{\mathrm{cx}}$ \\
\hline & 45 & - & $2.01 \pm 0.10^{\mathrm{cy}}$ & $4.67 \pm 0.25^{\mathrm{dx}}$ \\
\hline & 15 & - & $1.56 \pm 0.09^{\text {cy }}$ & $3.67 \pm 0.16^{\mathrm{dx}}$ \\
\hline \multirow[t]{3}{*}{30} & 30 & - & $1.07 \pm 0.02^{\mathrm{cy}}$ & $2.05 \pm 0.04^{\mathrm{dx}}$ \\
\hline & 45 & - & - & $1.33 \pm 0.02^{\mathrm{dx}}$ \\
\hline & 15 & - & - & $1.33 \pm 0.01^{\mathrm{dx}}$ \\
\hline \multirow[t]{2}{*}{45} & 30 & - & - & $1.33 \pm 0.01^{\mathrm{dx}}$ \\
\hline & 45 & - & - & $1.33 \pm 0.01^{\mathrm{dx}}$ \\
\hline
\end{tabular}

${ }^{1)}$ Values are means $\pm S D(n=3)$.

2)a-c The values with different letters in the same column are significantly different $(\mathrm{p}<0.05)$.

${ }^{3) \times-2}$ The values with different letters in the same low are significantly different $(\mathrm{p}<0.05)$.

\section{물성 변화}

이산화염소 가스 훈증 농도 및 시간에 따른 곶감의 물성 변화는 Table 4에 나타내었다. Hardness의 경우 대조군은 저장 기간 동안 계속 증가하였으며, 이산화염소 가스 훈증 처리 시에도 훈증 농도 및 시간에 관계없이 증가하는 모습 을 보였다. Hardness의 증가는 저장기간 동안 곶감의 수분 함량 변화에 의한 결과로 생각되며, 이산화염소 가스 처리 는 큰 영향을 미치지 않은 것으로 나타났다. Adhesiveness를 비롯한 cohesiveness, springiness, gumminess 및 chewiness 의 경우에도 대조군은 저장기간 동안 증가하는 경향을 보였 
Table 4. Changes of texture in dried persimmon treated with different concentration of chlorine dioxide gas and time during storage

\begin{tabular}{|c|c|c|c|c|c|c|c|c|c|c|c|}
\hline \multirow{2}{*}{\multicolumn{2}{|c|}{$\frac{\mathrm{ClO}_{2} \text { gas conc. (ppm) }}{\text { Time (min) }}$}} & \multirow{2}{*}{$\begin{array}{l}0 \\
0\end{array}$} & \multicolumn{3}{|c|}{15} & \multicolumn{3}{|c|}{30} & \multicolumn{3}{|c|}{45} \\
\hline & & & 15 & 30 & 45 & 15 & 30 & 45 & 15 & 30 & 45 \\
\hline \multirow{3}{*}{$\begin{array}{l}\text { Hardness } \\
(\mathrm{g})\end{array}$} & 1day & $298.50 \pm 77.13^{(122)(353)}$ & $330.92 \pm 110.89^{\text {ay }}$ & $275.33 \pm 65.07^{\text {ay }}$ & $274.92 \pm 46.98^{\text {ay }}$ & $285.58 \pm 64.19^{\text {ay }}$ & $237.67 \pm 55.21^{\text {ay }}$ & $257.92 \pm 69.82^{a y}$ & $360.08 \pm 49.69^{a y}$ & $258.08 \pm 87.43^{a y}$ & $249.14 \pm 53.56^{\text {ay }}$ \\
\hline & 2day & $437.58 \pm 57.36^{a y}$ & $445.58 \pm 57.51^{\text {ay }}$ & $492.83 \pm 176.99^{2 x y}$ & $549.33 \pm 130.11^{\text {ax }}$ & $423.17 \pm 113.05^{\text {axy }}$ & $642.58 \pm 178.24^{a x}$ & $543.50 \pm 154.78^{\text {ax }}$ & $539.54 \pm 65.73^{2 x}$ & $456.14 \pm 76.72^{\text {axy }}$ & $547.92 \pm 120.23^{a x}$ \\
\hline & 3day & $725.25 \pm 75.21^{2 x}$ & $688.92 \pm 152.9^{2 x}$ & $756.08 \pm 212.21^{2 x}$ & $654.70 \pm 123.10^{\text {abx }}$ & $623.15 \pm 203.28^{\text {alcox }}$ & $552.08 \pm 114.34^{\text {alcx }}$ & $368.25 \pm 48.78^{c x y}$ & $414.58 \pm 98.83^{\text {bxxy }}$ & $542.25 \pm 146.74^{\text {abcx }}$ & $681.24 \pm 140.13^{2 \mathrm{bx}}$ \\
\hline \multirow{3}{*}{$\begin{array}{l}\text { Adhesiveness } \\
\text { (mJ) }\end{array}$} & 1day & $0.51 \pm 0.21^{\mathrm{abz}}$ & $0.51 \pm 0.17^{\mathrm{abz}}$ & $0.79 \pm 0.16^{\text {aby }}$ & $0.65 \pm 0.09^{\mathrm{abz}}$ & $0.50 \pm 0.14^{\mathrm{abz}}$ & $0.46 \pm 0.14^{\mathrm{bz}}$ & $0.39 \pm 0.21^{\text {by }}$ & $0.94 \pm 0.48^{\text {ay }}$ & $0.72 \pm 0.38^{\mathrm{abz}}$ & $0.46 \pm 0.17^{\text {by }}$ \\
\hline & 2 day & $2.18 \pm 0.83^{\text {cdy }}$ & $1.99 \pm 0.50^{\text {cdy }}$ & $9.22 \pm 1.61^{b x}$ & $1.32 \pm 0.15^{\mathrm{dy}}$ & $3.55 \pm 0.59^{\mathrm{cdx}}$ & $4.04 \pm 0.56^{c \mathrm{x}}$ & $2.53 \pm 0.35^{\mathrm{cdx}}$ & $15.73 \pm 3.07^{\mathrm{ax}}$ & $1.81 \pm 0.18^{\text {ddy }}$ & $1.53 \pm 0.76^{\mathrm{dy}}$ \\
\hline & 3day & $4.04 \pm 1.08^{c x}$ & $5.77 \pm 1.09^{b x}$ & $2.37 \pm 0.14^{\mathrm{fy}}$ & $3.86 \pm 0.37^{\mathrm{d} d x}$ & $1.78 \pm 0.55^{\text {ey }}$ & $2.27 \pm 0.29^{\text {ey }}$ & $2.47 \pm 0.75^{\operatorname{dex}}$ & $2.69 \pm 0.95^{\text {cdey }}$ & $3.04 \pm 0.42^{\text {clex }}$ & $7.33 \pm 1.18^{\mathrm{ax}}$ \\
\hline \multirow{3}{*}{ Resilience } & 1day & $0.23 \pm 0.13^{\text {ax }}$ & $0.19 \pm 0.01^{\mathrm{abx}}$ & $0.14 \pm 0.01^{\mathrm{bx}}$ & $0.17 \pm 0.01^{\mathrm{abx}}$ & $0.19 \pm 0.01^{\mathrm{abx}}$ & $0.16 \pm 0.02^{\mathrm{abx}}$ & $0.19 \pm 0.01^{\mathrm{abx}}$ & $0.15 \pm 0.01^{\text {aby }}$ & $0.15 \pm 0.01^{\mathrm{abx}}$ & $0.17 \pm 0.01^{\mathrm{abx}}$ \\
\hline & 2day & $0.06 \pm 0.01^{\text {by }}$ & $0.08 \pm 0.01^{\text {by }}$ & $0.07 \pm 0.01^{b z}$ & $0.10 \pm 0.02^{\mathrm{by}}$ & $0.05 \pm 0.01^{b z}$ & $0.08 \pm 0.02^{\mathrm{by}}$ & $0.07 \pm 0.02^{\text {by }}$ & $0.75 \pm 0.14^{\mathrm{ax}}$ & $0.13 \pm 0.05^{b x}$ & $0.10 \pm 0.05^{\text {by }}$ \\
\hline & 3day & $0.06 \pm 0.01^{\text {cdy }}$ & $0.07 \pm 0.01^{\mathrm{cy}}$ & $0.09 \pm 0.01^{\text {by }}$ & $0.05 \pm 0.01^{1^{2}}$ & $0.11 \pm 0.01^{\mathrm{ay}}$ & $0.07 \pm 0.01^{\mathrm{cy}}$ & $0.06 \pm 0.01^{\text {cdy }}$ & $0.06 \pm 0.01^{\text {cdy }}$ & $0.09 \pm 0.01^{b x}$ & $0.05 \pm 0.01^{\mathrm{dy}}$ \\
\hline \multirow{3}{*}{ Cohesiveness } & 1day & $0.54 \pm 0.01^{\text {by }}$ & $0.57 \pm 0.01^{\text {bx }}$ & $0.50 \pm 0.10^{b x}$ & $0.54 \pm 0.07^{\mathrm{bx}}$ & $0.55 \pm 0.06^{\mathrm{bx}}$ & $0.52 \pm 0.03^{\mathrm{bx}}$ & $0.55 \pm 0.05^{b x}$ & $0.48 \pm 0.04^{\mathrm{bx}}$ & $0.51 \pm 0.03^{\mathrm{bx}}$ & $1.88 \pm 0.27^{a x}$ \\
\hline & 2day & $0.35 \pm 0.01^{\mathrm{dy}}$ & $0.37 \pm 0.01^{d y}$ & $0.38 \pm 0.05^{\text {cdx }}$ & $0.43 \pm 0.04^{\text {aby }}$ & $0.37 \pm 0.03^{\mathrm{dy}}$ & $0.39 \pm 0.01^{\text {bady }}$ & $0.42 \pm 0.02^{\mathrm{abcy}}$ & $0.38 \pm 0.02^{\text {cdy }}$ & $0.44 \pm 0.01^{\text {ay }}$ & $0.38 \pm 0.01^{\text {cdy }}$ \\
\hline & 3day & $1.72 \pm 0.21^{\mathrm{ax}}$ & $0.55 \pm 0.02^{b x}$ & $0.45 \pm 0.11^{\mathrm{bcdx}}$ & $0.36 \pm 0.02^{\text {dy }}$ & $0.44 \pm 0.01^{\text {bcdy }}$ & $0.39 \pm 0.02^{\text {cdy }}$ & $0.31 \pm 0.01^{\text {d }}$ & $0.36 \pm 0.01^{\text {cdy }}$ & $0.48 \pm 0.03^{\text {bxy }}$ & $0.55 \pm 0.04^{\text {by }}$ \\
\hline \multirow{3}{*}{$\begin{array}{l}\text { Springiness } \\
(\mathrm{mm})\end{array}$} & 1day & $4.81 \pm 0.20^{\text {cy }}$ & $5.84 \pm 0.54^{\mathrm{abz} z}$ & $5.00 \pm 0.55^{\text {bcy }}$ & $4.93 \pm 0.48^{\mathrm{cy}}$ & $6.02 \pm 0.88^{\text {ay }}$ & $4.63 \pm 0.36^{c y}$ & $5.12 \pm 0.47^{\text {bcy }}$ & $5.02 \pm 0.21^{\text {bcy }}$ & $4.66 \pm 0.19^{\text {cy }}$ & $5.08 \pm 0.24^{b c z}$ \\
\hline & 2day & $9.18 \pm 1.18^{\text {abcex }}$ & $9.64 \pm 1.21^{\text {abcy }}$ & $8.24 \pm 0.54^{\text {box }}$ & $8.97 \pm 0.77^{\text {abcx }}$ & $7.92 \pm 0.86^{c y}$ & $10.96 \pm 1.28^{2 x}$ & $10.18 \pm 1.77^{\mathrm{abx}}$ & $8.33 \pm 1.76^{b c x}$ & $10.94 \pm 0.72^{2 \mathrm{x}}$ & $9.92 \pm 0.67^{\text {abcy }}$ \\
\hline & 3day & $10.55 \pm 1.08^{\mathrm{bcx}}$ & $13.80 \pm 1.19^{2 \mathrm{xx}}$ & $9.32 \pm 1.21^{\mathrm{cdx}}$ & $9.21 \pm 1.28^{\operatorname{cdx}}$ & $10.24 \pm 1.16^{b \mathrm{bx}}$ & $9.73 \pm 1.04^{\mathrm{cdx}}$ & $8.64 \pm 1.07^{\mathrm{cdx}}$ & $7.71 \pm 1.11^{\mathrm{dx}}$ & $12.25 \pm 1.31^{a b x}$ & $12.89 \pm 1.94^{\mathrm{ax}}$ \\
\hline \multirow{3}{*}{$\begin{array}{l}\text { Gumminess } \\
(\mathrm{g})\end{array}$} & 1day & $151.83 \pm 16.88^{\text {by }}$ & $186.97 \pm 12.78^{a y}$ & $138.60 \pm 17.64^{\mathrm{dat} z}$ & $148.02 \pm 16.03^{\text {ddy }}$ & $158.65 \pm 12.66^{\text {by }}$ & $122.72 \pm 12.72^{d z}$ & $141.75 \pm 11.62^{\text {cdy }}$ & $176.45 \pm 12.40^{\text {aby }}$ & $138.58 \pm 16.97^{\mathrm{d} / \mathrm{z}}$ & $135.12 \pm 12.83^{\text {cdz }}$ \\
\hline & 2day & $152.27 \pm 13.98^{\mathrm{ey}}$ & $165.22 \pm 15.25^{\text {dey }}$ & $195.47 \pm 18.47^{\alpha y y}$ & $219.97 \pm 16.65^{\text {bcx }}$ & $156.33 \pm 18.67^{\mathrm{ey}}$ & $249.23 \pm 14.55^{b x}$ & $311.82 \pm 25.92^{2 x}$ & $244.18 \pm 17.66^{b x}$ & $195.28 \pm 14.15^{\text {cdy }}$ & $208.82 \pm 18.38^{\mathrm{cy}}$ \\
\hline & 3day & $268.73 \pm 13.34^{b x}$ & $326.05 \pm 18.68^{\mathrm{ax}}$ & $315.22 \pm 11.03^{2 x}$ & $240.42 \pm 14.02^{\mathrm{c} d x}$ & $270.22 \pm 17.42^{b x}$ & $214.93 \pm 14.31^{\text {dy }}$ & $113.28 \pm 15.21^{\mathrm{fy}}$ & $147.07 \pm 14.33^{\mathrm{ey}}$ & $248.27 \pm 14.54^{\text {bcx }}$ & $340.13 \pm 18.47^{\mathrm{ax}}$ \\
\hline \multirow{3}{*}{$\begin{array}{l}\text { Chewiness } \\
\text { (mJ) }\end{array}$} & 1day & $7.37 \pm 0.93^{\mathrm{ddz}}$ & $10.86 \pm 1.06^{\mathrm{ax}}$ & $6.94 \pm 0.65^{\mathrm{dz}}$ & $7.23 \pm 0.81^{\mathrm{ddz}}$ & $8.45 \pm 0.51^{\text {bzz }}$ & $5.35 \pm 0.69^{\mathrm{ez}}$ & $7.19 \pm 0.58^{\text {ddy }}$ & $9.22 \pm 0.66^{\text {bcy }}$ & $6.86 \pm 0.42^{\mathrm{dz}}$ & $6.75 \pm 0.53^{\mathrm{d} z}$ \\
\hline & 2day & $14.73 \pm 0.81^{\text {efy }}$ & $15.76 \pm 1.51^{\text {defy }}$ & $17.93 \pm 1.37^{\text {bodey }}$ & $19.59 \pm 1.83^{\text {body }}$ & $13.80 \pm 1.36^{\text {efy }}$ & $16.73 \pm 1.05^{\text {cdey }}$ & $41.21 \pm 5.29^{\mathrm{ax}}$ & $12.36 \pm 1.28^{\mathrm{fx}}$ & $20.96 \pm 1.51^{\text {by }}$ & $20.14 \pm 1.77^{\text {bcy }}$ \\
\hline & 3day & $30.86 \pm 2.04^{c x}$ & $47.81 \pm 2.18^{\mathrm{ax}}$ & $28.26 \pm 1.02^{\mathrm{cddx}}$ & $26.11 \pm 1.14^{e x}$ & $26.92 \pm 1.29^{\mathrm{dex}}$ & $20.29 \pm 1.83^{\mathrm{fx}}$ & $9.08 \pm 1.79^{\mathrm{gy}}$ & $11.66 \pm 1.71^{\mathrm{gxy}}$ & $29.51 \pm 1.15^{\mathrm{cdx}}$ & $43.95 \pm 2.25^{b x}$ \\
\hline
\end{tabular}

${ }^{1)}$ Values are means $\pm \mathrm{SD}(\mathrm{n}=15)$.

2)a-c The values with different letters in the same column are significantly different $(\mathrm{p}<0.05)$.

${ }^{3) \times-z}$ The values with different letters in the same lows are significantly different $(\mathrm{p}<0.05)$.

Table 5. Changes of color value in dried persimmon treated with different concentration of chlorine dioxide gas and time during storage

\begin{tabular}{|c|c|c|c|c|c|c|c|c|c|c|c|}
\hline \multicolumn{2}{|c|}{ ClO2 gas conc. (ppm) } & \multirow[t]{2}{*}{0} & \multicolumn{3}{|c|}{15} & \multicolumn{3}{|c|}{30} & \multicolumn{3}{|c|}{45} \\
\hline Time (min) & & & 15 & 30 & 45 & 15 & 30 & 45 & 15 & 30 & 45 \\
\hline \multirow{3}{*}{ L (lightness) } & 1day & $26.27 \pm 1.43^{1 \mathrm{ab}(\mathrm{a} 2) \times 33}$ & $23.73 \pm 1.85^{\mathrm{bdx}}$ & $25.34 \pm 1.09^{\mathrm{abcx}}$ & $27.54 \pm 0.37^{\mathrm{ax}}$ & $24.27 \pm 2.95^{\mathrm{abcdx}}$ & $26.30 \pm 0.86^{\mathrm{abx}}$ & $22.47 \pm 2.52^{\mathrm{cdx}}$ & $22.94 \pm 3.18^{\text {bcdx }}$ & $21.50 \pm 2.33^{\mathrm{dy}}$ & $22.55 \pm 0.72^{\text {body }}$ \\
\hline & 2day & $25.35 \pm 1.08^{2 x}$ & $26.63 \pm 4.55^{2 \mathrm{x}}$ & $23.93 \pm 2.30^{2 x}$ & $24.94 \pm 3.31^{2 x}$ & $27.36 \pm 2.08^{2 x}$ & $26.72 \pm 4.58^{\mathrm{ax}}$ & $23.51 \pm 5.00^{2 x}$ & $24.22 \pm 0.22^{2 \mathrm{xx}}$ & $27.51 \pm 2.67^{\mathrm{ax}}$ & $27.64 \pm 0.33^{2 x}$ \\
\hline & 3day & $24.51 \pm 2.70^{\mathrm{ax}}$ & $23.75 \pm 0.45^{-\mathrm{ax}}$ & $29.02 \pm 4.47^{2 \mathrm{xx}}$ & $26.76 \pm 4.75^{\mathrm{ax}}$ & $24.97 \pm 2.89^{\mathrm{ax}}$ & $26.63 \pm 2.34^{2 x}$ & $25.17 \pm 2.79^{2 x}$ & $24.91 \pm 2.63^{2 \mathrm{x}}$ & $27.39 \pm 1.03^{a x}$ & $27.07 \pm 2.11^{\mathrm{ax}}$ \\
\hline \multirow{3}{*}{ a (redness) } & 1day & $9.46 \pm 1.11^{\mathrm{ax}}$ & $8.48 \pm 0.95^{\text {abcx }}$ & $8.41 \pm 1.71^{\text {abcx }}$ & $9.05 \pm 1.18^{\text {abcx }}$ & $7.15 \pm 0.85^{\text {cdey }}$ & $8.85 \pm 0.63^{\mathrm{abx}}$ & $7.36 \pm 0.24^{\text {bady }}$ & $6.57 \pm 0.19^{\operatorname{dey}}$ & $7.69 \pm 0.32^{\text {bddy }}$ & $5.72 \pm 0.30^{\text {ey }}$ \\
\hline & 2day & $8.55 \pm 0.51^{b c d x y}$ & $9.38 \pm 0.92^{\text {abcx }}$ & $6.71 \pm 0.95^{\mathrm{ex}}$ & $9.80 \pm 0.55^{\mathrm{abx}}$ & $10.69 \pm 1.69^{a x}$ & $8.63 \pm 0.77^{\mathrm{bcdx}}$ & $8.68 \pm 0.36^{\text {badx }}$ & $7.39 \pm 0.50^{\mathrm{dexy}}$ & $8.96 \pm 0.76^{\mathrm{bcdx}}$ & $7.79 \pm 0.83^{\text {cdex }}$ \\
\hline & 3day & $7.86 \pm 0.24^{\text {abcy }}$ & $6.62 \pm 0.78^{c y}$ & $9.27 \pm 1.77^{\mathrm{abx}}$ & $10.17 \pm 2.99^{2 x}$ & $7.28 \pm 1.02^{\text {by }}$ & $8.09 \pm 0.94^{\text {abcox }}$ & $8.86 \pm 0.83^{\text {alcx }}$ & $8.70 \pm 1.02^{\text {abcx }}$ & $9.42 \pm 0.68^{\mathrm{abx}}$ & $9.29 \pm 1.08^{\mathrm{abx}}$ \\
\hline \multirow{3}{*}{ b (yelllowness) } & 1day & $9.05 \pm 1.09^{\mathrm{ax}}$ & $7.82 \pm 0.69^{\mathrm{abcx}}$ & $8.81 \pm 0.73^{\text {aby }}$ & $9.21 \pm 1.33^{2 x}$ & $7.59 \pm 0.14^{\text {bcy }}$ & $8.27 \pm 1.13^{\mathrm{abx}}$ & $7.48 \pm 0.50^{\operatorname{bxx}}$ & $6.78 \pm 0.31^{\mathrm{y}}$ & $6.69 \pm 0.44^{\mathrm{cy}}$ & $6.61 \pm 0.20^{c y}$ \\
\hline & 2day & $8.10 \pm 0.71^{b c x}$ & $8.83 \pm 0.90^{\mathrm{abcx}}$ & $6.96 \pm 0.57^{c y}$ & $8.93 \pm 1.16^{\mathrm{abcx}}$ & $10.31 \pm 1.25^{\mathrm{ax}}$ & $9.63 \pm 1.11^{\mathrm{abx}}$ & $8.04 \pm 1.23^{\operatorname{lox}}$ & $8.07 \pm 0.23^{\text {bcx }}$ & $8.88 \pm 1.35^{\text {abcx }}$ & $8.68 \pm 1.13^{\mathrm{abcx}}$ \\
\hline & 3day & $7.38 \pm 0.68^{c x}$ & $7.46 \pm 0.42^{c x}$ & $11.10 \pm 1.76^{\mathrm{ax}}$ & $9.75 \pm 1.02^{\mathrm{abx}}$ & $8.81 \pm 1.28^{\text {bxy }}$ & $8.77 \pm 0.70^{b c x}$ & $7.69 \pm 0.84^{c x}$ & $7.96 \pm 0.26^{b c x}$ & $8.94 \pm 0.86^{b c x}$ & $8.98 \pm 1.30^{b c x}$ \\
\hline \multirow{3}{*}{$\begin{array}{c}\Delta \mathrm{E} \text { (total } \\
\text { color difference) }\end{array}$} & 1day & $74.18 \pm 1.23^{\mathrm{bodx}}$ & $76.46 \pm 1.66^{\text {abcx }}$ & $74.99 \pm 0.81^{b c d x}$ & $72.94 \pm 0.60^{\mathrm{dx}}$ & $75.78 \pm 2.76^{\text {abcdx }}$ & $74.02 \pm 0.66^{\mathrm{d} x}$ & $77.57 \pm 2.29^{\mathrm{abx}}$ & $76.99 \pm 2.90^{\text {abcx }}$ & $78.49 \pm 2.23^{\mathrm{ax}}$ & $77.25 \pm 0.71^{\text {abx }}$ \\
\hline & 2day & $74.89 \pm 0.73^{2 x}$ & $72.66 \pm 3.85^{2 x}$ & $75.97 \pm 2.09^{a x}$ & $76.62 \pm 3.39^{2 x}$ & $73.46 \pm 1.63^{2 x}$ & $73.81 \pm 3.77^{2 \mathrm{x}}$ & $76.73 \pm 4.50^{2 x}$ & $75.74 \pm 0.24^{2 x}$ & $73.48 \pm 2.70^{\text {ay }}$ & $72.60 \pm 0.09^{a y}$ \\
\hline & 3day & $75.58 \pm 2.40^{a x}$ & $76.20 \pm 0.42^{a x}$ & $71.86 \pm 3.76^{\mathrm{ax}}$ & $74.01 \pm 3.39^{\mathrm{ax}}$ & $75.22 \pm 2.61^{a x}$ & $73.66 \pm 2.02^{\mathrm{ax}}$ & $75.08 \pm 2.34^{a x}$ & $75.33 \pm 2.32^{\mathrm{ax}}$ & $73.07 \pm 1.02^{\text {ay }}$ & $73.40 \pm 1.75^{\mathrm{ay}}$ \\
\hline
\end{tabular}

\footnotetext{
${ }^{1)}$ Values are means $\pm \mathrm{SD}(\mathrm{n}=10)$.

2)a-c The values with different letters in the same column are significantly different $(\mathrm{p}<0.05)$.

${ }^{3) x-2}$ The values with different letters in the same low are significantly different $(p<0.05)$.
} 
으며, resilience만 감소하였다. Hardness와 마찬가지로 이산 화염소 가스 훈증 처리 시 곶감의 물성은 큰 변화를 보이지 않았으며, 훈증 농도 및 시간 역시 영향을 미치지 않는 것으 로 나타났다.

Yoon 등(14)은 이슬송이버섯에 이산화염소 가스를 처리 한 후 조직감을 측정한 결과, hardness, springiness, cohesiveness, gumminess 및 chewiness는 대조군의 경우 저장 중 지속적으 로 감소하였으며, 이산화염소 처리군은 대조군에 비해 서 서히 감소하는 것으로 나타났다고 보고하여 본 실험과 상이 한 결과를 나타내었다. 이는 실험에 사용된 원료의 차이에 기인한 것으로 생각된다.

\section{색도 변화}

이산화염소 가스 훈증 농도 및 시간에 따른 곶감의 색도 변화는 Table 5 에 나타내었다. Lightness의 경우 대조군은 저장 3 일 동안 큰 변화는 없는 것으로 나타났다. 이산화염소 가스를 훈증 농도 및 시간을 달리하여 처리하였을 때는 저장기간에 따라 값이 약간의 변화를 보였지만 대조군과 비교하였을 때 큰 변화는 없는 것으로 나타났다. Redness와 yellowness 측정 결과, 대조군은 저장기간 동안 그 값이 약 간 감소하는 것으로 나타났지만 이산화염소 훈층 처리 시에 는 훈증 농도 및 시간에 따라 값의 차이를 보였지만 일정하 게 증가하거나 감소하는 경향을 보이지 않았다. 이러한 차 이는 이산화염소 훈증 처리에 의한 것이 아니라 측정을 위해 선별된 시료에 의한 차이로 생각된다. 색차 측정 결과 또한 이산화염소 훈증 처리에 의한 값의 차이는 나타나지 않았다.

Lee 등(13)은 수출딸기의 이산화염소 가스 처리에 의한 색도변화를 측정한 결과, $\mathrm{L}, \mathrm{a}, \mathrm{b}$ 값은 이산화염소 가스 처리구와 무처리구 사이에 유의적인 차이가 없다고 보고하 였고, 이산화염소 가스 처리에 의한 파프리카의 색도 변화 를 측정한 연구(20)에서도 저장 중 처리 유무에 의한 차이가 나타나지 않았다고 보고하여 본 실험 결과와 같은 경향을 나타내었다.

\section{요 약}

본 연구는 저장 및 유통과정 중 곶감의 품질 변화를 방지 하기 위한 방법으로 기존에 사용되어 왔던 유황 훈증 대체 물질로 이산화염소 훈증 방법의 효과를 확인하고자 하였 다. 곳감을 이산화염소 가스 훈증 농도 $(0,15,30,45 \mathrm{ppm})$ 및 시간 $(0,15,30,45 \mathrm{~min})$ 에 따라 처리한 후 상온에서 보관 하면서 미생물학적 변화, 물성 및 색도를 관찰하였다. 이산 화염소 가스 훈증 처리 후 총 호기성 세균과 효모 및 곰팡이 수는 대조구와 비교하였을 때 미생물 수가 감소하였으며, 총 호기성 세균의 저해 효과는 저장기간 동안 지속되었고,
효모 및 곰팡이 수의 경우에도 총 호기성 세균과 유사한 경향을 나타내었다. 곶감의 물성 및 색도는 이산화염소 가 스 훈증 농도 및 시간에 의해 영향을 받지 않는 것으로 나타났다. 이산화염소 가스 훈증 처리는 곶감의 저장 중 미생물학적 안전성 확보를 위한 처리 기술로 활용될 수 있을 것으로 기대된다.

\section{감사의 글}

본 연구는 농촌진흥청 공동연구사업(과제번호:PJ01166401) 의 지원에 의해 이루어진 것으로 감사드립니다.

\section{References}

1. Kim JK, Kang WW, Oh SL, Kim JH, Han JH, Moon HK, Choi JU (2004) Comparison of quality characteristics on traditional dried persimmons from various regions. J Korean Soc Food Sci Nutr, 33, 140-145

2. Im JS, Lee MH (2007) Physicochemical compositions of raw and dried Wolha persimmons. Korean J Food Preserv, 14, 611-616

3. Lee YR, Chung HS, Moon KD (2011) Change in the polyphenol content of Cheongdobansi persimmon fruit during development. Korean J Food Preserv, 18, 13-17

4. Hong EY, Kim YC, Rhee CH, Kang WW, Choi JU, Chung SK (2001) Changes of microflora in processing and preservation of dried persimmon. Korean J Postharvest Sci Technol, 8, 374-378

5. Lim BS, Lee SH, Hwang YS (2011) Influence of SO2 generating pad treatment on storage of grape berries. CNU J Agric Sci, 38, 607-612

6. Oh SI, Kim CW, Lee U (2016) Effect of SO2 generating pad treatments on the quality of dried persimmons during storage. J Korean For Soc, 105, 202-207

7. Lee SW, Moon HY, Lee WY, Kim JK (2011) Physicochemical characteristics of cold-air dried persimmons and traditional dried persimmons. Korean J Food Preserv, $18,481-487$

8. Gomez-Lopez VM, Ragaert P, Jeyachchandran V, Debevere J, Devlieghere F (2008) Shelf-life of minimally processed lettuce and cabbage treated with gaseous chlorine dioxide and cysteine. Int J Food Microbiol, 121, 74-83

9. Kim JM (2001) Use of chlorine dioxide as a biocide in the food industry. Food Industty and Nutrition, 6, 33-39 
10. Kim YJ, Kim MH, Song KB (2009) Efficacy of aqueous chlorine dioxide and fumaric acid for inactivating pre-existing microorganisms and Escherichia coli O157:H7, Salmonella typhimurium, and Listeria monocytogenes on broccoli sprouts. Food Control, 20, 1002-1005

11. Han Y, Linton RH, Nielsen SS, Nelson PE (2001) Reduction of Listeria monocytogenes on green peppers (Capsicum annuum L.) by gaseous and aqueous chlorine dioxide and water washing and its growth at $7^{\circ} \mathrm{C}$. J Food Prot, 64, 1730-1738

12. Youm HG, Ko JK, Kim MR, Cho YS, Chun HK, Song KB (2005) Effect of aqueous chlorine dioxide and citric acid treatment on microbial safety and quality control of minimally processed and refrigerated (MPR) salad. Korean J Food Sci Technol, 37, 129-133

13. Lee HS, Shim WB, An HM, Ha JH, Lee ES, Kim WI, Kim HY, Kim SR (2016) Antimicrobial effects of chlorine dioxide gas on pathogenic Escherichia coli and Salmonella spp. colonizing on strawberries for export. J Food Hyg Saf, 31, 451-457

14. Yoon YT, Bong SJ, Kang HS, Yoon YJ, Kim HG, Min KH, Lee KH (2016) Quality changes of Lentinula edodes GNA01 mushroom by choline dioxide gas treatment during storage. Korean J Food Nutr, 29, 499-505

15. Ku KJ, Ma YH, Shin HY, Lee SW, Park JH, Kim LH, Song KB (2006) Effects of chlorine dioxide treatment on quality and microbial change of Agaricus bisporus Sing during storage. J Korean Soc Food Sci Nutr, 35, 955-959

16. Han Y, Guentert AM, Smith RS, Linton RH, Nelson PE (1999) Efficacy of chlorine dioxide gas as a sanitizer for tanks used for aseptic juice storage. Food Microbiol, $16,53-61$

17. Mahmoud BSM, Bhagat AR, Linton RH (2007) Inactivation kinetics of inoculated Escherichia coli O157:H7, Listeria monocytogenes and Salmonella enterica on strawberries by chlorine dioxide gas. Food Microbiol, 24, 736-744

18. Bhagat A, Mahmoud BSM, Linton RH (2010) Inactivation Salmonella enterica and Listeria monocytogenes inoculated on hydroponic tomatoes using chlorine dioxide gas. Foodborne Pathog Dis, 7, 677-685

19. Sy KV, McWatters KH, Beuchat LR (2005) Efficacy of gaseous chlorine dioxide as a sanitizer for killing Salmonella, yeasts, and molds on blueberries, strawberries, and raspberries. J Food Prot, 6, 1165-1175

20. Kang JH, Park SM, Kim HG, Son HJ, Song KJ, Cho M, Kim JR, Lee JY, Song KB (2016) Effects of combined chlorine dioxide gas treatment using low-concentration generating sticks on the microbiological safety and quality of paprika during storage. J Korean Soc Food Sci Nutr, 45, 619-624 